\title{
THE INFLUENCE OF SOME INSECT GROWTH REGULATORS AND BIO-INSECTICIDES AGAINST COTTON LEAFWORM AND SOME ASSOCIATED PREDATORS UNDER FIELD CONDITIONS
}

\author{
Desuky, W. M. ${ }^{1}$, E. F. El-Khayat ${ }^{2}$, M. M. Azab ${ }^{2}$ and M. M. Khedr ${ }^{1}$ \\ 1. Plant Protection Research Institute, ARC, Dokki, Giza, Egypt. \\ 2. Plant Protection Department, Faculty of Agric. Benha Univ., Egypt
}

(Manuscript received 21 June 2011)

\begin{abstract}
Experiments were carried out at Zagazig district, Sharqia Governorate during two successive seasons, 2007 \& 2008 to evaluate the toxicity of some insecticides against $S$. littoralis larvae infesting cotton cultivations and some associated common predators.

Chlorpyrifos and methoxyfenozide were the most potent insecticide in both initial and residual effect that caused highly significant reduction in the infestation rates of the pest as compared to other treatments at the initial and residual effects that recorded $(98.21 \pm 0.783,82.55 \pm 2.444 \%)$ as initial effect and $(93.34 \pm 2.599,85.32 \pm 2.195 \%)$ as residual effect during 2007 while during 2008 season it recorded $(96.01 \pm .0 .723,83.97 \pm 3.462 \%)$ and $(89.89 \pm 2.715,86.34 \pm 3.398 \%)$ for initial and residual effect, respectively. Considering the initial and residual effects of the rest treatments, it could be arranged descendingly as teflubenzuron, tebufenozide, Tracer and finally Dipel $2 \mathrm{X}$ at both tested seasons.

Chlorpyrifos and methoxyfenozide were the most toxic insecticides causing the highest significant reduction in the predator numbers that recorded $(79.81 \pm 3.544,24.73 \pm 2.162 \%)$ and $(66.81 \pm 5.418, \quad 29.36 \pm 3.468 \%)$ at 2007 and $(71.60 \pm 3.84$, $23.50 \pm 1.799 \%)$ and $(64.91 \pm 3.569,26.78 \pm 3.548)$ at 2008 in the initial and residual effects, respectively. Followed by Tracer, teflubenzuron, tebufenozide and Dipel $2 X$ during the two successive seasons
\end{abstract}

\section{INTRODUCTION}

Cotton, Gossypium barbadense (L.) occupies a prominent position in Egyptian agriculture. It is still the main cash crop for a sizeable selection of Egyptian farmers. Besides it is the main raw material for the largest national industry, the textile industry, as well as the main source of locally produced cotton seed oil. However, cotton plants are liable to be attacked by several pests all over the growing stages that affected and negatively its productivity.

The noctuid Spodoptera littoralis (Boisduval) is a major polyphagous pest, widely distributed throughout Africa, Mediterranean Europe, and several parts of Asia (Hosny and Isshak, 1967). To combat the pest, growers use synthetic organic insecticides and some biorational agents such as Bacillus thuringiensis Berliner, but 
the control achieved is not successful because of the insect's high capacity to develop resistance toward the majority of conventional compounds. Therefore, scientists and growers are seeking alternative materials that are effective against this pest, safe to humans, environmental friendly, and compatible within targeted pest management (IPM) practices. The alternative control tactics that show promise as a potential tool in $S$. littoralis resistant management programs is the use of biorational control agents such as synthetic insect growth regulators (IGRs) and those based on naturally derived products. IGRs are claimed to be safer for beneficial organisms such as predators than conventional products, and they have been successfully used in IPM programs against many tree and small fruit pests. Many predatory insects recorded in the cotton fields in Egypt and the reverse action of applied insecticides against them was studied (Desuky, 2002).

The objective of this study was to evaluate the toxicity of Teflubenzuron, Tebufenozide, Methoxyfenozide, Spinosad, Dipel 2x and chlorpyrifos against cotton leafworm, $S$. littoralis larvae and associated predators under field conditions.

\section{MATERIALS AND METHODS}

\section{Tested compounds:}

\subsection{Insect growth regulators:}

A. Trade name: Nomolt ${ }^{\circledR}$ 15\% Suspension Concentrate (SC).

Common name: Teflubenzuron.

Rate: $50 \mathrm{~cm}^{3} / 100 \mathrm{~L}$.

Basic product: BASF Co.

B: Trade name: Mimic ${ }^{\circledR}$ 24\% Emulsifiable Concentrate (EC).

Common name: Tebufenozide.

Rate: $350 \mathrm{~cm}^{3}$ /feddan.

Basic product: Dow AgroSciences.

C: Trade name: Runner ${ }^{\circledR}$ 24\% Suspension Concentrate (SC).

Common name: Methoxyfenozide.

Rate: $150 \mathrm{~cm}^{3}$ / feddan.

Basic product: Dow AgroSciences Co. 


\subsection{Bio-insecticides:}

\section{A. Trade name: Tracer $^{\circledR}$}

Common name: Spinosad 24\% Suspension Concentrate (SC). Tracer is comprised primarily of two macrocyclic lactones, Spinosyn A and D, secondary metabolites produced by the actinomycete, Saccharopolyspra spinosa under natural fermentation condition.

Rate: $50 \mathrm{~cm}^{3}$ / feddan.

Basic product: Dow AgroSciences Co.

\section{B: Trade name: Dipel $2 X^{\circledR}(6.4 \%$ WP).}

Common name: Bacillus thuringiensis subsp. Kurstaki 32, 000 International Units of potency per $\mathrm{mg}$.

Rate: 500 gram / feddan

Basic product: Chemical and Agricultural Products Division, Abbott Laboratories USA.

\subsection{Organophosphorus insecticide:}

- Trade name: Dursban ${ }^{\circledR}$ (48\% EC).

Common name: Chlorpyrifos.

Rate: 1 liter / feddan.

Basic product: Dow AgroSciences.

\section{Methods of application}

These trials were carried at Zagazig district, Sharqia Governorate, during 2007 and 2008 cotton growing seasons to evaluate the efficiency of six insecticides against the cotton leafworm, $S$. littoralis and some common predators. This evaluation was assessed on the basis the reduction percentages in both $S$. littoralis and predators.

An area of about quarter feddan cultivated with cotton variety (Giza 86) was chosen for each insecticide and control as well. Each area was divided into four experimental plots as replicates. Untreated belt $(42 \times 7 \mathrm{~m})$ was left between each two treatments as a border.

Larvae were counted while newly hatched ones were neglected from counting. A pre-treatment count was made for each treatment. Post treatments counts were recorded after $1,3,5,7$, and 9 days for chlorpyrifos, Dipel $2 X$ and Tracer, 5, 10 and 15 days for IGRs (teflubenzuron, tebufenozide and methoxyfenozide).

The tested insecticides were applied at the recommended field rate, while control was sprayed with water only using a knapsack motor sprayer, 20 liter in capacity used with 200 -liter volume of insecticidal solution per feddan. The 
percentage of reduction in the population density of $S$. littoralis was estimated using the equation of Henderson and Tilton (1955).

The initial kill was calculated at one day post treatment for chlorpyrifos, Dipel 2X and Tracer, whereas after 5 days was determined IGRs (teflubenzuron, tebufenozide and methoxyfenozide). While, the general mean residual effect was calculated as the mean reduction percentages of larvae observed at days 3, 5, 7, and 9 post treatment for chlorpyrifos, Dipel $2 X$ and Tracer, compared to 10,15 for IGRs (teflubenzuron, tebufenozide and methoxyfenozide), (Badr, 2000).

At the same inspected times, the lethal effects of different insecticides and control against common predators: ladybird beetles, Coccinella spp., Scymnus spp., the aphid lion, Chrysoperla carnea Steph., the staphylinid beetle, Paederus alfierii Koch, the anthocorid bugs, Orius spp. and true spider were also studied using Henderson and Tilton equation (1955).

The significance of the main effects was determined by analysis of variance (ANOVA). The significance of various treatments was evaluated by Duncan's multiple range test $(p<0.05)$ (Snedecor \& Cochran 1980). Data were subjected to statistical analyses using a software package CoStat ${ }^{\circledR}$ Statistical Software (2005) a product of Cohort Software, Monterey, California.

\section{RESULTS AND DISCUSSION}

\section{Effects of the tested insecticides against larvae of cotton leafworm, $S$. littoralis under field conditions:}

Data concerning Tables ( $1 \& 2$ ) summarize the efficiency of some insecticides against S. littoralis infestation during 2007 and 2008 seasons. All the investigated insecticides at the recommended concentrations exhibited reduction in infestation of S. littoralis on cotton plants compared to control.

The initial effect measured as the reduction percentages of $S$. littoralis larvae at the first day post treatment for chlorpyrifos, at the third post treatment for Tracer and Dipel $2 X$ and at the fifth day post treatment for IGRs was determined. The difference in the times of initial effect was due to the mode of action of each insecticide.

Through the season 2007 the initial effect of chlorpyrifos methoxyfenozide, teflubenzuron, tebufenozide, Tracer and Dipel $2 X$, respectively recorded $98.21 \pm 0.783$, $82.55 \pm 2.444,80.83 \pm 2.151,72.70 \pm 1.910,39.57 \pm 2.030$ and $16.20 \pm 1.720 \%$ (Tables 1 \& 2). 
The same trend was recorded in season 2008, showing chlorpyrifos as the highest initial effect $(96.01 \pm 0.723 \%)$ while Dipel $2 X$ gave the lowest effect $(15.29 \pm 1.401 \%)$.

As for IGRs, the initial effect ranged between $73.23 \pm 4.084 \%$ for tebufenozide and $83.97 \pm 3.462 \%$ for methoxyfenozide. There were non significant differences among treatments. Whereas the residual effect measured as the mean reduction percentages of larvae at days of 3, 5, 7 and 9 post treatment for chlorpyrifos, compared to 5, 7 and 9 days post treatment for Tracer and Dipel 2X, whereas the residual effect of IGRs was assed at 10 and 15 days post treatment .

The values of residual effect were recorded $93.34 \pm 2.599 \%$ for chlorpyrifos, $85.32 \pm 2.195$ for methoxyfenozide, $81.59 \pm 2.777 \%$ for teflubenzuron $77.93 \pm 2.125$ for Tracer and $20.55 \pm 1.798$ for Dipel $2 X$ at the first implemented season.

During the second season 2008, the residual effect of the tested insecticides ranged between $18.82 \pm 2.038 \%$ for Dipel $2 X$ to $89.89 \pm 2.751 \%$ in case of chlorpyrifos. The residual effect of methoxyfenozide recorded $86.34 \pm 3.398 \%$ followed by $83.34 \pm 3.353 \%$ for teflubenzuron and $52.21 \pm 2.931 \%$ for Tracer, (Tables $1 \& 2$ ).

The obtained results raveled that chlorpyrifos (Dursban) was the most potent insecticide in both initial and residual effect that caused highly significant effect as compared to the other treatments during 2007 and 2008, seasons. Considering the initial effects, the rest of treatments could be arranged descendingly as follows: methoxyfenozide teflubenzuron, tebufenozide, Tracer and finally Dipel $2 \mathrm{X}$ at both tested seasons.

Only chlorpyrifos have higher initial effects than its residual effects comparing to the other tested insecticides. The results are in agreement with the data recorded by Abd El-Latief, (2001) who reported that, the organophosphorus compound (chlorpyrifos) exhibited high initial kill against the cotton leafworm larvae after three days of treatment, then the mortality was decreased steadily. Chlorpyrifos was the superior insecticide in activity followed by profenofos.

The residual reduction percentages of (IGRs) and bio-insecticides increased than that of initial effects during the two successive seasons, indicating that the effectiveness of both insecticides increased with increasing the time. The present results corroborates those of El-Maghraby et al., (1999) who investigated three IGRs applied at the recommended and half recommended rates, compared to three conventional insecticides against $S$. littoralis during 1997 and 1998 seasons. Different rates of spinosad were applied to lettuce and compared to a normal dose of deltamethrin (pyrethroid). All spinosad rates applied 20 days after transplanting 
controlled $S$. littoralis for the whole crop. They stated that the persistence of spinosad reached up to 45 days after treatment.

Dipel $2 X$ (B. thuringiensis) gave the least significant effective in the initial and residual effects during the two successive seasons. Also, Cordero et al., 2006 found that Acetamiprid, B. thuringiensis was inconsistent in its performance in field experiments against some lepidopteran pests and Dipel $2 X$ produced similar level for $S$. littoralis control as thecarbamate insecticide, Lannate. Whereas, B. thuringiensis compounds, Dipel 2X, MVPII and Dipel ES/NT revealed initial mortality lower than that obtained with the chemical insecticides, Lannate and Reldan, but residual toxicity after 7 days of application for the entomopathogenic bacteria was higher than the chemical insecticides.

\section{Effects of the tested insecticides on some common predators associated with the cotton leafworm under field conditions:}

The aim of this experiment is to investigate the side effect of the tested insecticides on reducing populations of some common predators associated with cotton leafworm population, i.e. ladybird beetle, Coccinella spp., Scymnus spp., the aphid lion, Chrysoperla carnea Steph, the staphylinid beetle, Peaderus alferii Koch, the anthocorid bugs, Orius spp. and the true spiders in cotton fields during the two successive seasons, 2007 and 2008. The initial and residual effects of the tested insecticides were assessed using the reduction percentages of predators and calculated at the same inspected times of the precedent trial against the cotton leafworm, S. littoralis.

During the first inspected season 2007, data illustrated in Tables (3 \& 4) showed that chlorpyrifos recorded the highest significant initial and residual effects that gave reduction of $74.81 \pm 3.544$ and $66.81 \pm 5.418 \%$, respectively. The other tested compounds caused moderate effects that manifested $(24.73 \pm 2.162$ and $29.36 \pm 3.468 \%$ ) for methoxyfenozide, $21.58 \pm 3.453$ and $29.17 \pm 3.612 \%$ for Tracer, $20.18 \pm 1.449$ and $25.28 \pm 2.644 \%$ for teflubenzuron. While Dipel $2 X$ had the least values (12.71 2.099 and $16.46 \pm 2.890 \%)$, respectively.

The same trend was observed during 2008 season, with the exception of teflubenzuron and tebufenozide that changed their places between initial and residual effects as shown in Tables ( $3 \& 4$ ). Chlorpyrifos recorded the highest significant initial and residual effects on the previous predators, which being $71.60 \pm 3.84$ and $64.91 \pm 3.569 \%$ followed descendingly order of methoxyfenozide $(23.50 \pm 1.799$ and $26.78 \pm 3.548 \%)$, Tracer (22.42 \pm 2.931 and $26.92 \pm 3.24 \%)$, teflubenzuron $(21.65 \pm 2.496$ and $23.66 \pm 2.969 \%),(19.70 \pm 2.047$ and $24.34 \pm 2.781)$, 
respectively whereas Dipel $2 \mathrm{X}$ occupied the last category that recorded $(14.60 \pm 2.072$ and $17.68 \pm 3.586 \%)$, respectively

The mean number and reduction percentages in the population of the abovementioned predators that affected by the tested insecticides were tabulated in Tables (5-8) through the two successive seasons 2007 and 2008.

During 2007 season methoxyfenozide recorded the highest initial and residual effect among all tested IGRs against true spiders, Orius spp. and Scymnus spp. that manifested (38.63 \pm 3.49 and $27.27 \pm 3.51 \%),(20.63 \pm 3.29$ and $37.50 \pm 2.84 \%)$ and $(17.44 \pm 2.39$ and $21.94 \pm 2.72 \%)$, respectively.

Methoxyfenozide gave the highest initial effect on Chrysoperla carnea, Peaderus alfierii and Coccinella spp. that recorded reduction of 39.71 \pm 3.52 , $28.89 \pm 2.58$ and $20.95 \pm 3.13 \%$, respectively.

The highest residual effects were obtained by tebufenozide against both Coccinella spp. $(28.73 \pm 3.43 \%)$ and Peaderus alfierii $(20.00 \pm 2.48 \%)$ and by teflubenzuron against Chrysoperla carnea (54.89 $44.01 \%)$.

No significant differences were observed among the treatments in the initial and residual effect with the exception of tebufenozide and methoxyfenozide on Coccinella spp. and Scymnus spp., respectively in the residual effect (Table 5).

As for bio-insecticides and chlorpyrifos insecticide, the initial effects of chlorpyrifos ranged between a minimum value of $(65.28 \pm 4.77 \%)$ for Orius spp. to a maximum value of $(77.52 \pm 3.63 \%)$ for Scymnus spp., whereas the initial effect of Tracer ranged between $(3.10 \pm 0.40 \%)$ for Scymnus spp. to $(37.78 \pm 3.50 \%)$ for Peaderus alfierii. Dipel $2 \mathrm{X}$ ranged between $(4.51 \pm 0.62 \%)$ for Orius spp. to (24.71土2.77) for Chrysoperla carnea.

Chlorpyrifos caused the highest significant reduction percentages against tested predators, while Dipel $2 X$ gave the lowest reduction percentages (Table, 7 ).

In case of season 2008, methoxyfenozide recorded the highest significant


true spiders $(31.37 \pm 3.84$ and $21.42 \pm 1.64 \%)$ in the initial and residual effect, respectively. Also, recorded the highest reduction percentages than the other treatments against Peaderus alfierii $(41.67 \pm 3.50 \%)$ and Scymnus spp. $(19.41 \pm 1.46 \%)$ in the initial effect and Orius spp. $(30.66 \pm 2.73 \%)$ in case of residual effect (Table, 6). Tebufenozide gave the highest decrease in the population of Coccinella spp. (20.63 $\pm 2.33 \%)$ and Orius spp.(19.84 $2.18 \%)$ in the initial toxicity and Peaderus alfierii $(55.75 \pm 2.41 \%)$ and Scymnus spp. $(3.91 \pm 3.85 \%)$ in the residual toxicity without any significant differences among tested IGRs. 
Regarding the bio-insecticides and chlorpyrifos group, chlorpyrifos caused the highest significant reduction percentages in the initial and residual effect that ranged between minimum values of $(81.25 \pm 3.35$ and $77.19 \pm 3.38 \%)$ for Coccinella spp. Both Tracer and Dipel $2 X$ gave the highest initial and residual toxicity against populations of Chrysoperla carnea that manifested (55.56 $\pm 3.21 \& 55.92 \pm 2.57)$ and $(38.46 \pm 3.04 \&$ $36.18 \pm 2.65 \%$ ) in the initial and residual effects, respectively (Table, 8 ).

Populations of the predatory insects found in all treated areas with tested insecticides were significantly reduced comparing to predator numbers registered in the untreated areas during the two successive seasons.

Insect growth regulators and bio-insecticides caused lower effects against tested predators than chlorpyrifos. This may be attributed to the supposed selectivity of such insecticides that had low contact toxicity against insect species. Mandour (2009) found that spinosad was harmless to Chrysoperla carnea eggs and pupae irrespective of concentrations or method of application and he reported that buprofezin and cyromazine (IGRs) were innocuous to larvae and eggs of Chrysoperla spp. and were selective to immature phase. The results obtained in this topic are in complete agreement with the data recorded by (Duffie et al., 1998) when they tested different classes of insecticides against predators. They found that pyrethroid and organophosphorus classes were the most toxic causing dramatic reductions in the predator numbers, carbamate was moderately toxic. While bio-insecticides, IGRs and the naturalyte (spinosad) had low toxicity to predators.

Similarly, when adults obtained from laboratory colonies of predators were exposed to ten insecticides including four newer insecticides with novel modes of action there was considerable variation in response among the predators tested to the insecticides. In general, Malathion (organophosphorus) was the most toxic one, whereas spinosad was less toxic than the other insecticides against the tested predators, the same conclusions were also obtained by several authors (Desuky, 2002) when tested different insecticides against some common predators.

In addition, Cordero et al., (2006) found that among a group of different tested insecticides, spinosad and methoxyfenozide are relatively less toxic to natural enemies and thus can fit well into integrated pest management programs. All the tested insecticides with exception of chlorpyrifos have residual effects higher than their initial ones. 
Among the tested IGRs, methoxyfenozide was the most toxicant against the tested predaceous insects than both teflubenzuron and tebufenozide during the two successive seasons. In contrary, when Angeli et al., (2000) exposed the $4^{\text {th }}$ instar nymph of Orius laevigatus to eleven insect growth regulators. They found that methoxyfenozide, tebufenozide and triflumuron had no effect, teflubenzuron and buprofezin had slightly harmful and hexaflumuron, flufenoxuron and lufenuron had moderately harmful.

In general, Chrysoperla carnea was the most susceptible predators towards all tested insecticides whereas Scymnus spp. was the most tolerant one. These results are in harmony with findings of Fayad and Ibrahim (1988) who found C. Carnea was highly susceptible to deltamethrin, chlorpyrifos, diflubenzuron and profenofos, the first insecticide was the most critical in the disturbance of Scymnus and Orius spp. No significant differences were noted between the insecticides or interval between treatments. Peaderus alfierii and spiders appeared to tolerate the effects of the insecticides and were encountered in moderate numbers throughout the study, the same symmetry was ordered by same authors who reported that $C$. carnea was highly sensitive to most tested insecticides including spinosad that was less toxic than other insecticides tested against these species. 
40 THE INFLUENCE OF SOME INSECT GROWTH REGULATORS AND BIO-INSECTICIDES AGAINST COTTON LEAFWORM AND SOME ASSOCIATED PREDATORS UNDER FIELD CONDITIONS 
42 THE INFLUENCE OF SOME INSECT GROWTH REGULATORS AND BIO-INSECTICIDES AGAINST COTTON LEAFWORM AND SOME ASSOCIATED PREDATORS UNDER FIELD CONDITIONS 
44 THE INFLUENCE OF SOME INSECT GROWTH REGULATORS AND BIO-INSECTICIDES AGAINST COTTON LEAFWORM AND SOME ASSOCIATED PREDATORS UNDER FIELD CONDITIONS 
46 THE INFLUENCE OF SOME INSECT GROWTH REGULATORS AND BIO-INSECTICIDES AGAINST COTTON LEAFWORM AND SOME ASSOCIATED PREDATORS UNDER FIELD CONDITIONS 
48 THE INFLUENCE OF SOME INSECT GROWTH REGULATORS AND BIO-INSECTICIDES AGAINST COTTON LEAFWORM AND SOME ASSOCIATED PREDATORS UNDER FIELD CONDITIONS 
50 THE INFLUENCE OF SOME INSECT GROWTH REGULATORS AND BIO-INSECTICIDES AGAINST COTTON LEAFWORM AND SOME ASSOCIATED PREDATORS UNDER FIELD CONDITIONS 
52 THE INFLUENCE OF SOME INSECT GROWTH REGULATORS AND BIO-INSECTICIDES AGAINST COTTON LEAFWORM AND SOME ASSOCIATED PREDATORS UNDER FIELD CONDITIONS

\section{REFERENCES}

1. Abd El-Latief, E. M. 2001. Integrated pest management for cotton in Dakahlia Governorate. Ph. D. Thesis. Fac. Agric., Mansoura Univ., Egypt, 154 p.

2. Angeli, G., D. Forti, R. Maines, H. Vogt and U. Heimbach. 2000. Side-effects of eleven insect growth regulators on the predatory bug, Orius laevigatus Fiber (Heteroptera: Anthocoridae). Working group "Pesticides and beneficial organisms" Versailles, France 27-29 October 1999 Bulletin-OILB-SROP, 23(9): 85-92.

3. Badr, N. A. 2000. Efficiency of some natural products and insect growth regulator (Consult) against the cotton leafworm, Spodoptera littoralis (Boisd.). Egypt. J. Appl. Sci., 15 (9): 316-327.

4. Cordero, R. J., T. P. Kuhar, J. Speese, R. R. Youngman, E. E. Lewis, J. R. Bloomquist, L. T. Kok and A. D. Bratsch. 2006. Field efficacy of insecticides for control of lepidopteran pests on collards in Virginia. Plant Health Progress, (January): 1-9.

5. CoStat Statistical Software. 2005. Microcomputer program analysis version, 6 . 311. CoHort Software, Monterey, California.

6. Desuky, W. M. 2002. Methoxyfenozide, a new moulting accelerating compound for controlling the cotton leafworm at Sharkia Governorate, Egypt. Egypt. J. Appl. Sci., 17 (12): 752-763.

7. Duffie, W. D., M. J. Sullivan, S. G. Turnipseed, P. Dugger and D. Richter. 1998. Predator mortality in cotton from different insecticide classes. Proceedings Beltwide Cotton Conferences, San Diego, California, USA, 5-9 Jan., 2: 1111-1112.

8. El-Maghraby, H. M., M. H. El-Khawalla, M. A. El-Bessomy and H. I. Omar. 1999. Effect of three IGRs compared with chemical insecticides against cotton leafworm, Spodoptera littoralis (Boisd.) infesting tomato plants. $2^{\text {nd }}$ Int. Conf. of Pest Control, Mansoura, Egypt, Sept. 1999. 
9. Fayad, Y. H. and A. A. Ibrahim. 1988. Impact of successive insecticidal application at different interval periods on the number of predators in cotton fields. Bull. Entomol. Soc. Egypt, Econ. Ser., 15, 47-58.

10. Henderson, C. F. and E. W. Tilton. 1955. Tests with acaricides against the brown wheat mite. J. Econ. Entomol., 48 (2): 157-161. Informatore Agrario, 57 (5): 7476.

11. Hosny, M. M. and R. R. Isshak. 1967. New approaches to the ecology and control of three major cotton pests in U. A. R. Part 1: Factors stimulating the outbreaks of the cotton leafworm in U. A. R. and the principle of its predication. U. A. R. Minist. Agric. Tech. Bull., 1: 1-36.

12. Mandour, N. S. 2009. Influence of spinosad on immature and adult stages of Chrysoperla carnea (Stephens) (Neuroptera: Chrysopidae). BioControl, 54 (1): 93112.

13. Snedecor, G. W. and G. W. Cochran. 1980. Statistical methods $2^{\text {nd }}$ Ed. Iowa State Univ. Press Iowa, U S A. 


\section{تأثير بعض منظمات النمو الحشرية و المركبات الحيوية على دودة ورق القطن و بعض المفترسات المصاحبة لها تحت الظروف الحقلية

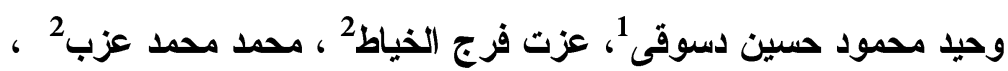 \\ محمد محمد احمد خضر 1 ترن

$$
\text { r - معرم وقابة النبات - كلبة الزقاية النباتات - مركز البحوث الزراعية - دقى - جيزة. }
$$

أجريت تجارب حقلية فى منطقة الزقازيق بمحافظة الشرقية خلال موسمى زر اعة القطن

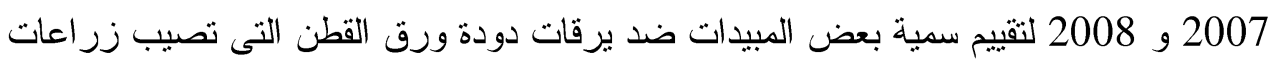

القطن بهذه المنطقة كذلك التاثير على بعض المفترسات المصاحبة لها، و قد أثنارت النتائج الى ان ان مركبى كلوربيريفوس و ميثوكسيفينوزيد هما أكثر المبيدات المختبرة فعالية حيث سجلا نسب لهبت إبادة

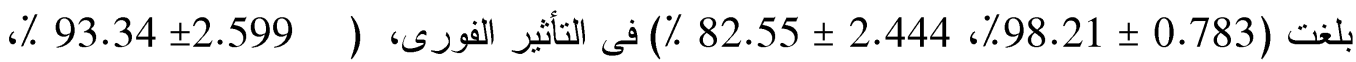
85.32_2.195 \%) فى التأثير المتبقي فى موسم 2007، مقارنة بقيم (

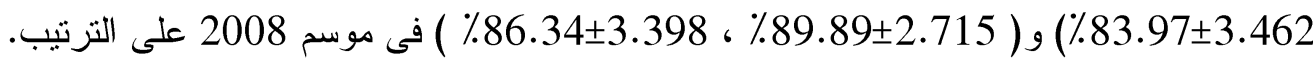
بالنسبة للتأثيرين الفورى و المتبقى لباقى المركبات المختبرة فيمكن ترتيبها تتازلياً كما يلى:

تيفلوبنزيرون و تيبوفينو زيد و نراسر و داييل تو اكس على مدار موسمى الدراسة.


المصاحبة لدودة ورق القطن فى حقول القطن حيث أعطيا اكبر نسبة خفض في التعداد بلغت



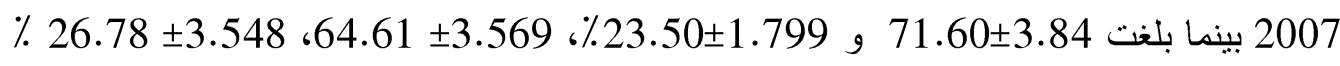


تيفلو بنزيرون و داييل نو اكس خلال موسمى الدر اسة. 